\title{
On the Appropriate Names for Snakes Usually Identified as Coluber rhodorachis (Jan, 1865) OR

\author{
Why Ecologists Should Approach \\ the Forest of Taxonomy with Great Care
}

Gad Perry

Department of Natural Resource Management, Texas Tech University, Lubbock, Texas 79409, USA (Gad.Perry@ttu.edu)

\section{Introduction}

E cologists and conservation biologists have to identify the organisms with which they work. With increasingly sophisticated methods to extract, analyze, and compare DNA, identity has become ever more complex, potentially informative, yet often infuriatingly fluid. When the information we need is not forthcoming from systematists, field biologists may be tempted to try and sort things out. This somewhat schizophrenic paper is the result of my foray into that realm. On the one hand, this article attempts to untangle the history and ferret out the proper names for the mostly-Asian

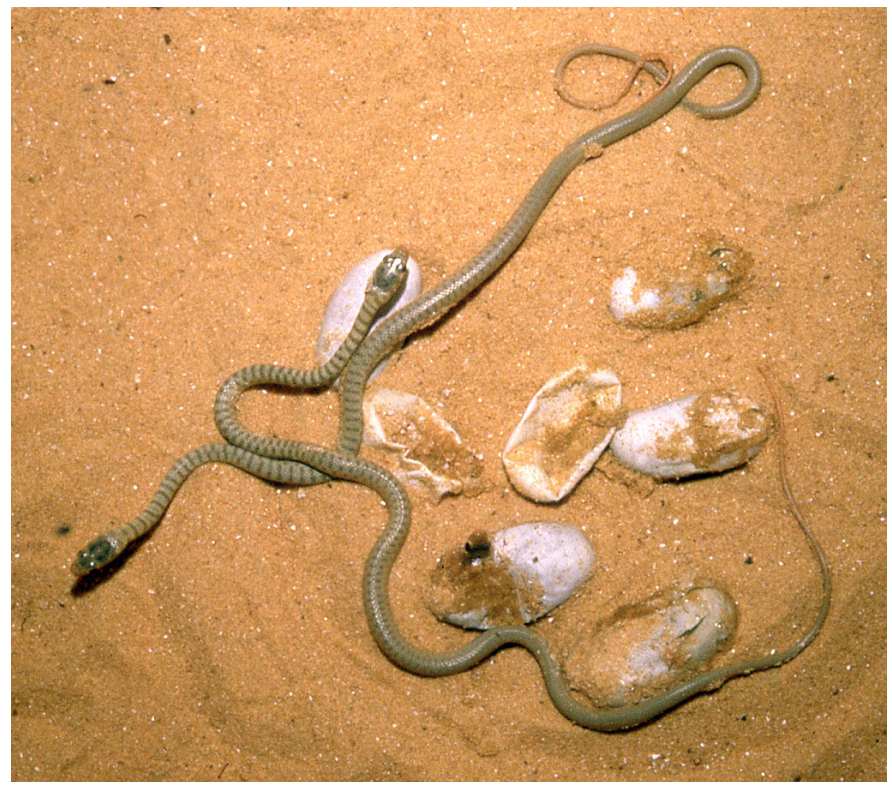

Fig. 1. Hatchling Platyceps tessellata (Werner, 1909), the form found in southern Israel and typical of desert habitats, emerging from a clutch laid at the I. Meier Segals Garden for Zoological Research at Tel Aviv University. Note that the dark cross-bands often break up into smaller elements around the middle of the body. Photograph by I. Movshovits.

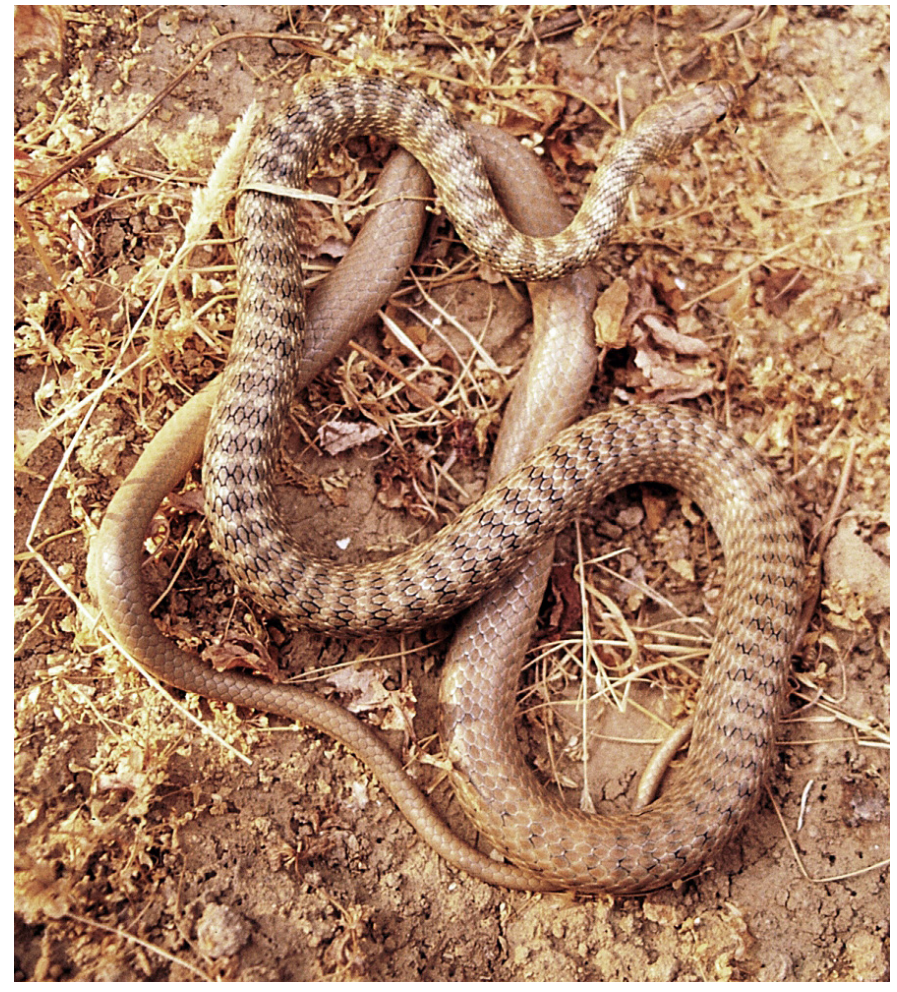

Fig. 2. An adult Platyceps tessellata. Note that the banded pattern tends to become faint toward the tail. Photograph by Gad Perry.

snakes often referred to - almost invariably erroneously as Coluber (originally Zamenis, at one point Gonyosoma and at another Haemorrhois, recently Platyceps) rhodorachis. On the other, it serves as a warning to those interested in the ecology and conservation of living organisms about the complexities and frustrations that can lurk down this path.

The phylogenetic relationships of snakes have been less extensively resolved than those of many other groups. One of the most problematic snake taxa is the genus Coluber, currently comprised 
mostly of Old World taxa, but also containing some New World species. For example, Schätti (1987) noted that the relationships within Coluber, as established by traditional morphological characters, are hard to characterize. Relationships within Coluber rhodorachis and among it and several closely allied taxa have proven especially intractable (Schätti 1987; Leviton et al. 1992, p. 92; Khan 1997; Schätti and Schmitz 2006). The genus is only briefly mentioned in newer works, such as Utiger et al. (2002, 2005), Nagy et al. (2004), and Lawson et al. (2005) — if at all. Although some of these authors placed the genus within a phylogenetic tree, and studies such as Nagy et al. (2004) suggested that Platyceps indeed forms a single clade, these studies did not seek to unravel the complex issues of what animals actually belong to it. One reason for this is the confusion in the literature regarding taxonomy of animals identified as $C$. rhodorachis. Different authors have used different spelling, recognized a different number of forms, and identified their distributions in markedly different ways. Here, I attempt to resolve this problem by summarizing the most relevant literature and examining additional specimens from the entire range of this taxon. I provide information on all described forms and evaluate

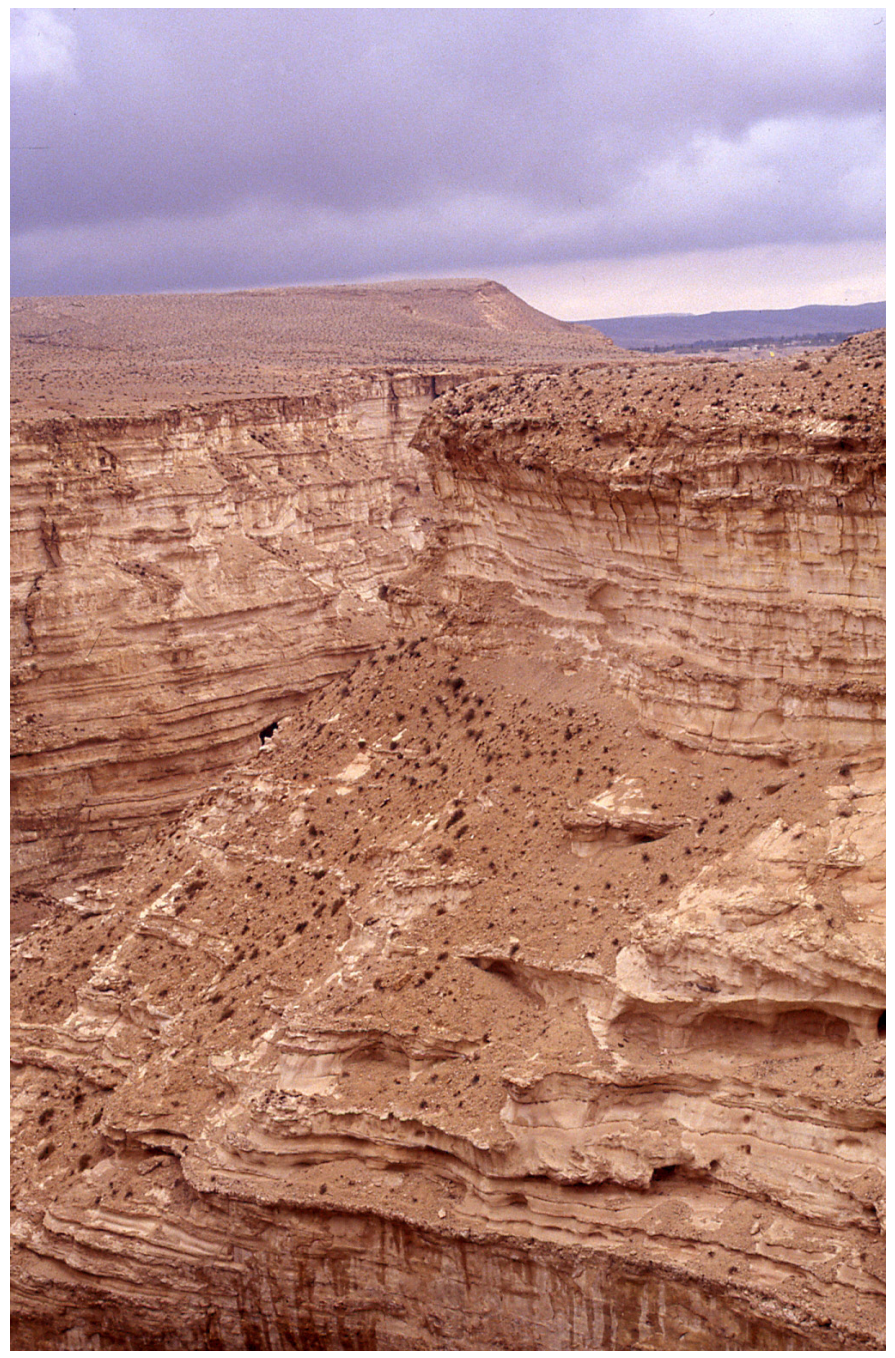

Fig. 3. A wadi (dry wash) in the Negev desert, Israel. The desert form shown in Fig. 1 can be seen in and around such locations. Photograph by Gad Perry. their validity using information based on key morphological characters. This story jumps around between two timelines. One is that of the species, which begins about 150 years ago with Europeans wandering around what was then called Persia (now Iran). The other is a personal timeline, which starts when I was in high-school in Israel and encountered my first Desert Racer ("za'aman dak" in Hebrew, which translates roughly as "slender irate snake," an apt name for this ill-tempered animal). To accommodate both perspectives and timelines I will switch from dry science to personal account, from my growing personal entanglement to the complex but fascinating history of naming these animals.

\section{How I Became Involved}

Growing up in Israel, my initial introduction to these snakes was through the only key and field guide to Israeli amphibians and reptiles available at the time (Barash and Hoofien 1966). The snake pictured, a desert animal, was identified as Coluber rhodorhachis. It looked like what I had been seeing (Figs. 1-2) in the Negev Desert, where I lived at the time (Figs. 3-4). Since I did not know Latin, I did not question why the scientific name referred to a red vertebral stripe that was

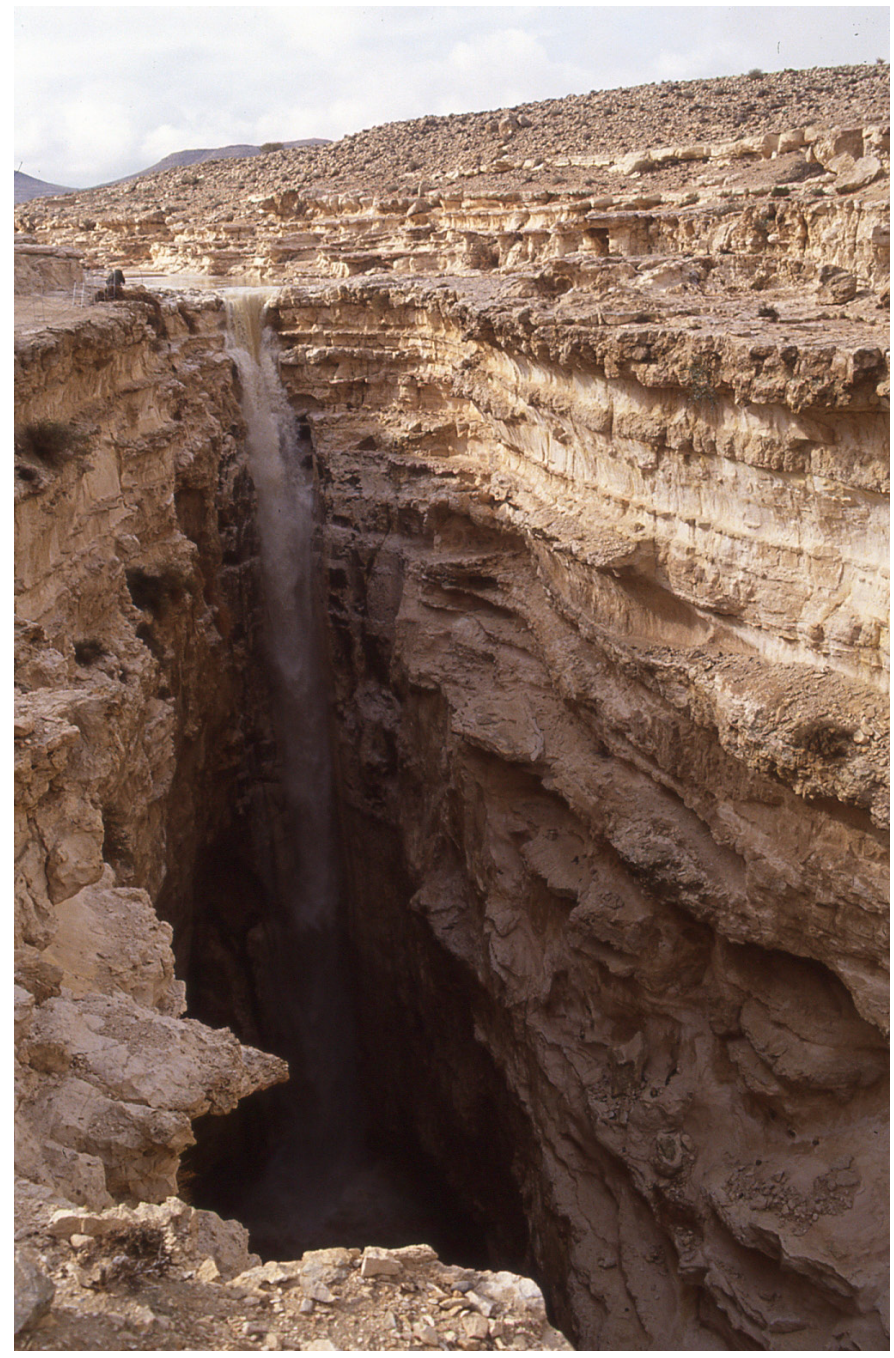

Fig. 4. A rare flash flood brings water to a Negev wadi. Normal annual rainfall in this region is around $100 \mathrm{~mm}$. Photograph by Gad Perry. 


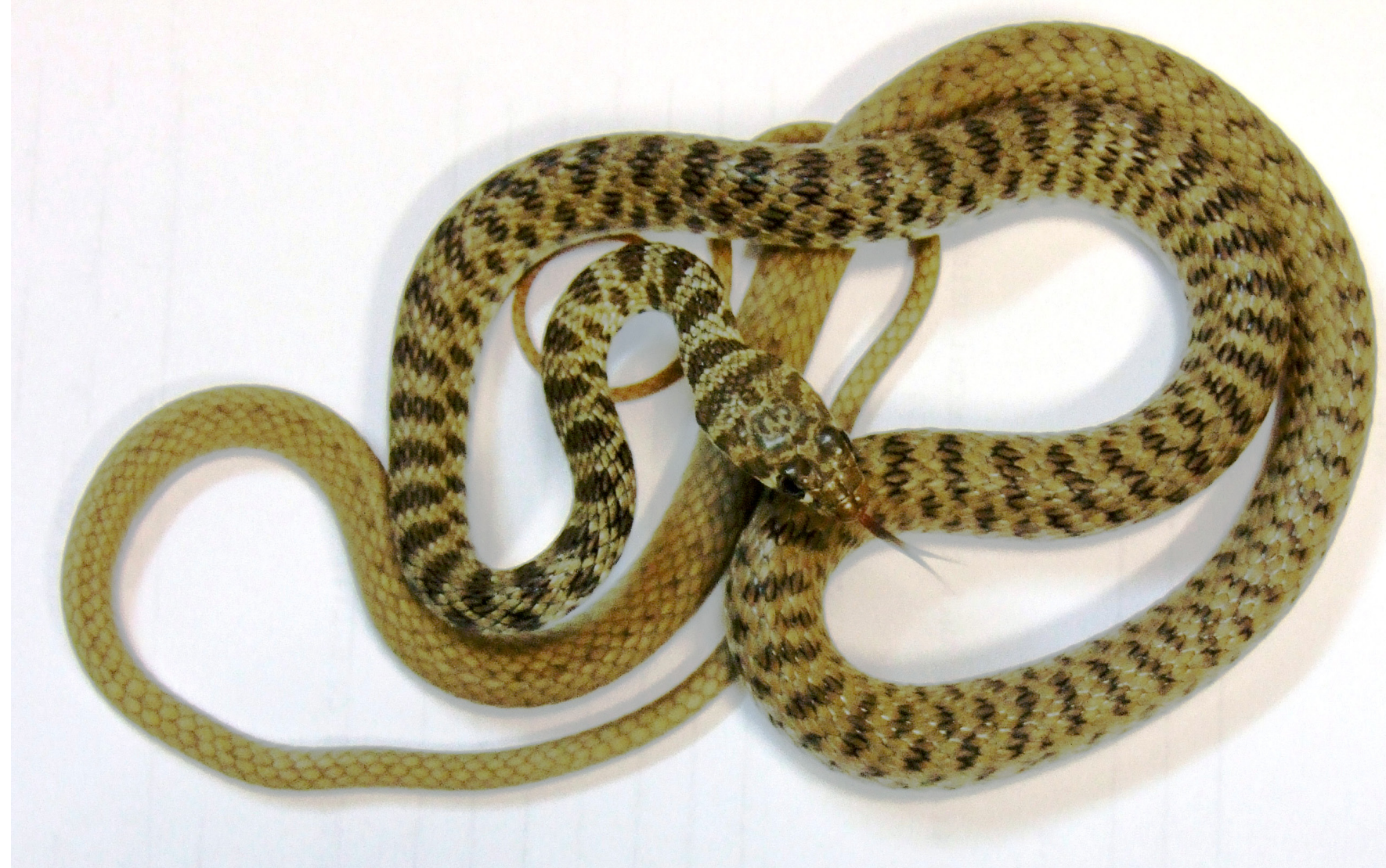

Fig. 5. Platyceps ladacensis (Anderson 1871), the form found in northern Israel and typical of relatively mesic habitats. Note the presence of a thin dark stripe between every pair of thick dorsal stripes, especially in the anterior part of the body. Photograph of an animal from near the town of Shoham by Boaz Shacham.

never seen in individuals from Israel. When the first color guide came out (Arbel 1984), an explanation was offered: The original animal, caught in Iran, had the red stripe, but this is only rarely seen in some large individuals, and disappears in preservative. I had just never seen one of those unusual individuals, I thought. I was wrong to accept that statement, but I did not learn that until much later.

What changed things for me was the capture of an animal that looked different (Fig. 5) in northern Israel in the early 1980s. Yehudah Werner, Hebrew University of Jerusalem (HUJ), and Amos Bouskila, now at Ben Gurion University, got me involved. They suggested that this could be the first instance of a related species, C. ventromaculatus, which had only a short time previously been found in Turkey. A bit of book research and the identification would be made certain, I figured. Alas, wrong again. The strange animal clearly was not $C$. ventromaculatus, which is characterized by distinctive ventral markings and neck pattern. Then, I discovered that our "mystery" animal really was not all that strange - several more like it were in the HUJ and Tel Aviv University (TAU) museum collections. In fact, Bodenheimer (1935) had already noted that two forms occurred in what would later be named Israel: "C. ventromaculatus lives around the Dead Sea ... C. rhodorhachis in the Negeb." Clearly, we had not been paying attention, but once again the value of having specimens in a museum jar was clearly shown, since I could examine them in detail. I found out that the two groups were consistently different not just in appearance and typical habitat but also in scale counts (more on this later). The conclusion seemed pretty clear. Since we already knew what the southern form was, the northern form must be a new taxon (Perry 1985). Wrong again: it turned out that we did not really know what the southern form was.

\section{Named Forms of "Coluber rhodorachis"}

To explain why the identification of the form we always thought we knew was wrong, I have to turn to some historical sleuthing. To describe a new organism, one must first show that it is different from what has been previously described. A comprehensive examination of the literature identified several named taxa that had previously been placed within $C$. rhodorachis. Here I briefly summarize, in chronological order, the distinguishing information provided by the original authors (the first use of a name is indicated in bold). Discussions below address the validity of each taxon, geographic distribution, scale counts, and the origin of the common misspellings of some of these names (all initial misspellings are listed). Spellings below follow those of the original authors. I avoid citing many publications that name or misidentify these snakes in ways previously covered, because this would greatly inflate the size of this article. 
1865: Günther (1858, p. 106) distinguished a variant of Coluber ventrimaculatus from what is now recognized as $C$. florulentus by coloration alone ("Var C. Olive, without cross bands; a broad rose-coloured band along the whole back; form and structure of head shields completely the same as in the following varieties"). Günther (1858) referred to two specimens, "adult and half-grown," collected in Shiraz (Iran) and Kurdistan (parts of which fall in modern Iraq, Iran, Turkey, and Syria).

1865: Zamenis rhodorachis was originally named with few distinguishing details (Jan 1865, p. 356). Jan's (1865) entire description is eight lines long, of which the quote from Günther (1858) takes up about half. Almost in passing, it distinguishes $C$. rhodorachis from C. florulentus by having "always 19 series [of scales across the midbody], and not 21" and "never [having] the transversal markings which distinguish Zamenis florulentus at first sight."

1871: Zamenis Ladacensis was described by Anderson (1871) from the mountainous region of Ladak (or Ladakh), Kashmir (now hotly disputed between India and Pakistan, and also partially administered by the People's Republic of China). Considerable detail was provided, including a ventral count of 237 and a detailed description of coloration. Anderson (1871) described this taxon as "pale olive brown, marked on the anterior half of the body by broad brown dorsal bands only a little darker than the general colour of the snake, distinct near the anterior part of the body, but obscure behind." The ventrals were described as "pale yellow," and dorsal scales had two apical pores. The type specimen had 102 pairs of subcaudal scales.

1872: Gonyosoma dorsale was also described by Anderson. The type specimen was collected in Shiraz, Iran, and was described as having "a bright pink longitudinal band" on a dorsal background that is "pale yellowish green." It had 227 keeled ventrals, 107 pairs of subcaudal scales, and an apical groove on each dorsal scale (Anderson 1872).

1891: Sclater (1891) included G. dorsalis as part of $Z$. ladaccensis and referred to specimens in the Indian Museum, "including the type of Gonyosoma dorsalis, Anders" from Shiraz, other "Persia" locations, and Pakistan (including Ladak, now under Indian control).

1893: Boettger (1893) named Zamenis ladacensis, var. subnigra from Ogaden, Somalia. The type specimen had a dark back, with different regions being described as gray-brown, black, or bluish-gray. The type has 213 ventral scales ranging in color from yellowish to gray and 118 pairs of subcaudals.

1893: Boulenger (1893), the major authority of the time, synonimized $Z$. ladacensis and $G$. dorsale with $Z$. rhodorachis. He identified two forms: Type A, with the pink vertebral stripe, is found in "Persia," and contains two previously named forms: $Z$. rhodorhachis and $G$. dorsale. It also is characterized by low ventral counts (217-228 in four specimens). Type B is identified as synonymous with $Z$. ladacensis, has no vertebral stripe, and is widely distributed (Egypt, Arabia, India, and Pakistan). The ventral count of these animals tends to be higher, but ranges broadly.

1895, 1898, 1901: Anderson (1895) followed Boulenger (1893), stating that his original specimens "are unquestionably identical with Jan's." He also adopted the use of rhodorhachis, a correction of the original Latin, but a misspelling according to the rules of nomenclature. Anderson noted that "the variation in the number of ventrals in this species is very great, ranging from 213 to 262. The higher number occurs in Egypt and in Midian [currently Jordan] ... in eastern and south-eastern Arabia, Muscat to Aden, the ventrals range from 220-239 ... From Bushire to Baluchistan [both now in Iran, GP] ... 214-218..." (Anderson 1895). Anderson (1898, pp. 252-254) described the animal as "olive-grey, with about 95 dark, narrow, closely set cross-bars on the anterior two-thirds of the trunk, the posterior third and the tail uniform olive-grey ... in some (Persian specimens) there is a pinkish vertebral line." He further added to the synonymy "Zamenis ladaccensis, var. subnigra," added "Somaliland" (portions of today's countries of Ethiopia, Eritrea, Somalia, and Somaliland) to the range, and noted that "in the Somaliland snakes the prevailing numbers are low, like those found on the opposite coast of the Straits of Aden." The habitat in Egypt was clearly described as desert (Anderson 1898). Anderson (1901) described animals that are "a uniform greyish-blue or slatecolor along two thirds of the length of the trunk, whereas the latter third and on the upper surface of the tail it passes into purplish brown." He noted that it "recalls in its coloration the snake from Ogaden in Somaliland described by Boettger under the name of $Z$. ladacensis var. subnigra, but differs from it in some details, but of such little importance that the type of coloration ... may be said to be common to individuals of $Z$. rhodorhachis from both sides of the Red Sea in the latitude of Aden."

1909: Zamenis rhodorhachis var. tessellata was described by Werner (1909) from a type specimen having three rows of dark splotches on the anterior dorsum, markings that become less distinct toward the uniformly light gray posterior. Dark splotches are found on both sides of each light-colored ventral scale.

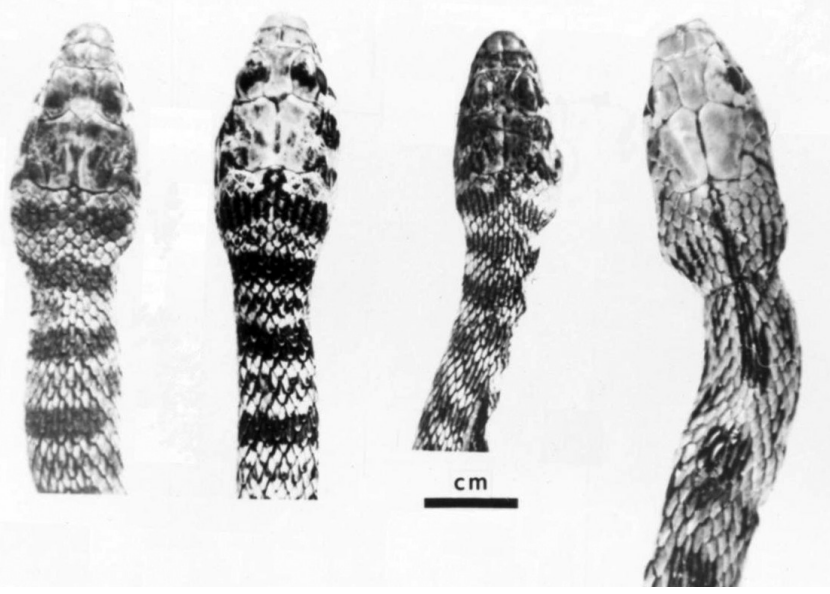

Fig. 6. A comparison of the patterns on the heads and necks of the northern form probably most accurately designated Platyceps ladacensis (individual from northern Israel, HUJ 8970, extreme left; individual from En Gedi, HUJ 8820, center left), the southern form best referred to $P$. tessellata (individual from Sedom, Israel, HUJ 3413, center right), and Coluber ventromaculatus (HUJ 3534, far right). Photograph by Y.L. Werner. 
1914: Zamenis rhodorachis, Z. ladacensis, and Gonyosoma dorsale are all considered by Wall to be junior synonyms of the previously-described $Z$. ventrimaculatus, and therefore invalid (Schätti and Schmitz 2006).

1943: The genus Platyceps, initially erected in 1860 by Blyth, was revived by Inger and Clark (1943), who placed rhodorachis in it.

1979: Sochurek (1979) added a new misspelling, Coluber rhodorhachus rhodorhachus, for animals located in "rocky deserts of Egypt to the Cyrenaika" (Libya).

1980s: Welch (e.g., 1982) placed rhodorachis in the genus Haemorrhois, first named in the 1820s by Boie.

2000: Coluber rhodorachis kashmirensis was described with a type locality of Kashmir (Khan and Khan 2000). The type specimen and paratypes were characterized by having low ventral (210-239) and subcaudal (119-135) counts. The head of this high-elevation form was described as "black ...

PLATE 16
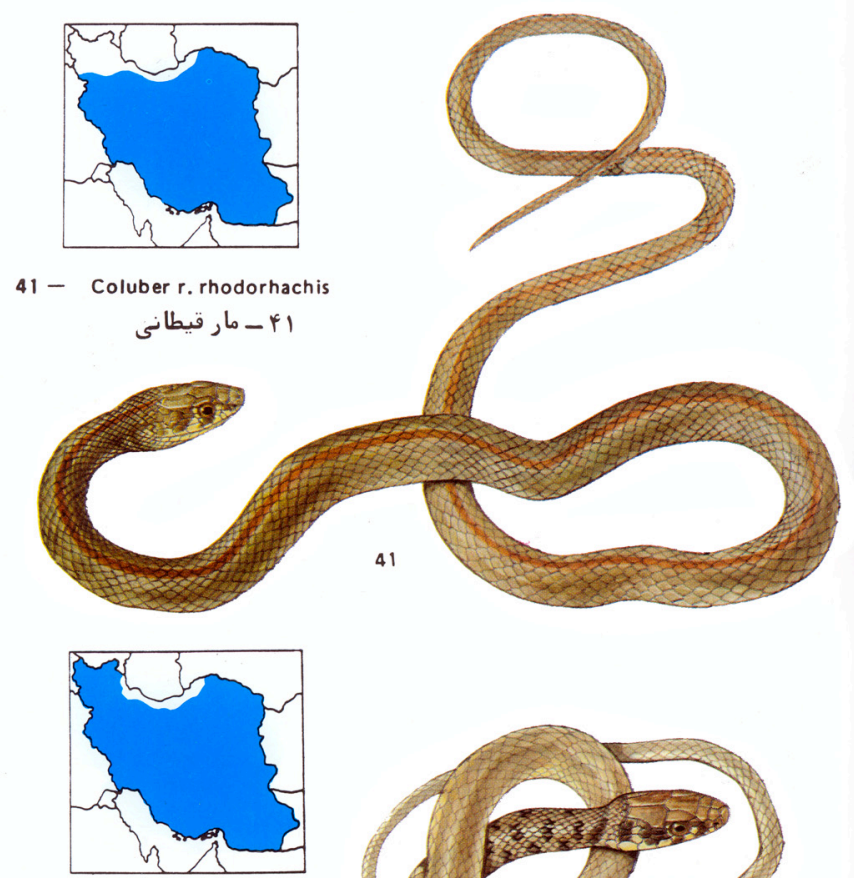

42 - Coluber r. ladacensis

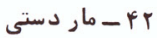

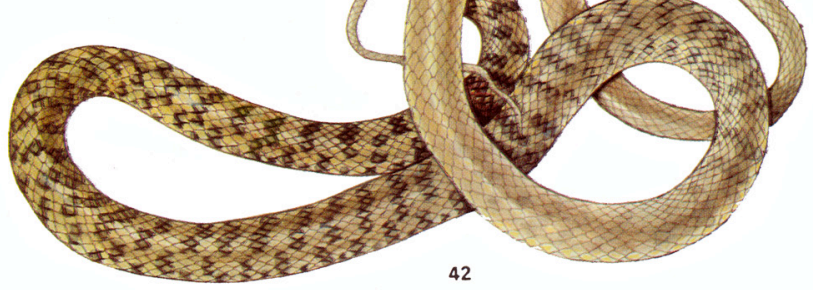

Fig. 7. Artist's rendition of Platyceps rhodorachis Jan (1865), the originally described red-striped animals from Asia (top), and the desert form, which should be called Platyceps tessellata (bottom). Reproduced from Latifi (1991. Snakes of Iran), courtesy of the Society for the Study of Amphibians and Reptiles.

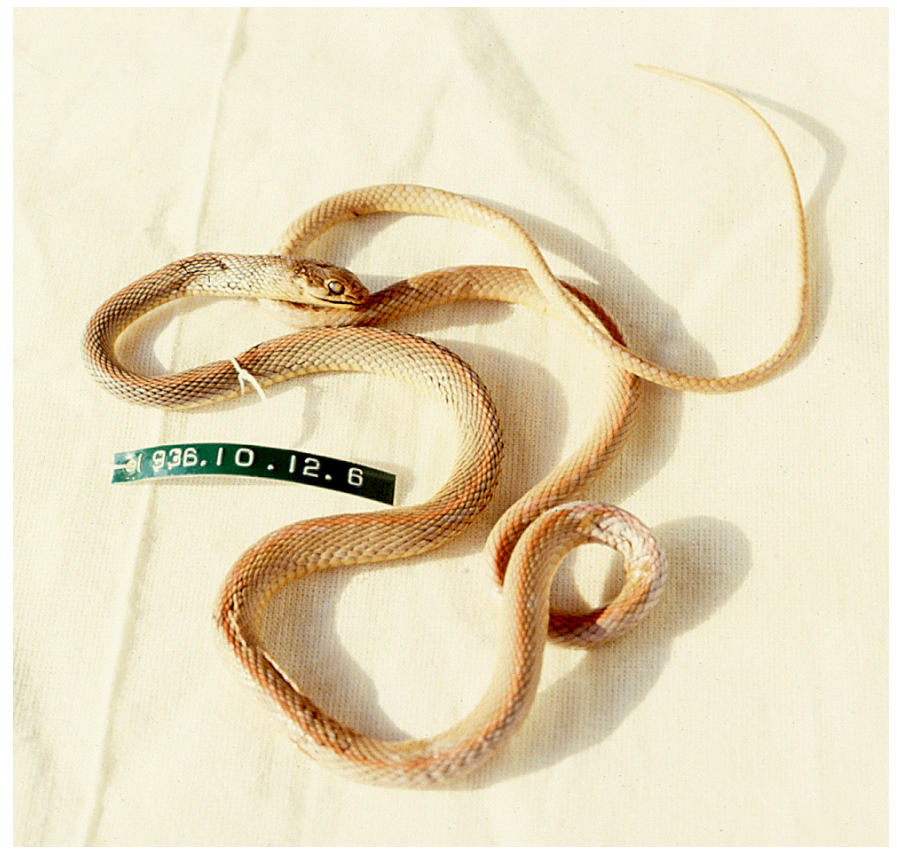

Fig. 8. Preserved Platyceps rhodorachis collected in Iran in 1936 and photographed at the Natural History Museum in London more than 50 years later. The red stripe remains clearly visible, as does the lack of cross-bands. Photograph by Gad Perry.

distinct light pre and postocular bars," the anterior half of body is "black with no indication of spotty pattern," and the posterior half of body is "lighter with dark irregular dashes." The abdominal scales are dark, with "pigment especially deposited between ventrals." The type specimen is deposited at the Natural History Museum, Lahore, Pakistan, and unfortunately is not available for inspection (M.S. Khan, pers. comm.), but a picture is provided in Khan and Khan (2000).

2004: Platyceps sabaricus is the most recently described addition to the $C$. rhodorachis "complex" (Schätti and McCarthy 2004). The authors included desert forms from Egypt and elsewhere comprising parts of multiple named taxa, including various spellings and misspellings of those above, as well as $C$. florulentus. The morphology of the new species was described in detail, with higher ventral counts being the primary distinguishing characteristic. Although "the species is named after the Sahara desert, its main distribution range," few records from the Sahara are actually indicated in the distribution map provided by Schätti and McCarthy (2004; see also Geniez and Gauthier 2008).

To make things even more confusing, in 2011, several web sites were mentioning "Eremiophis rhodorhachis" as a synonym, although none of them provide a reference to the source of the putative specific name and I have not been able to locate such a reference myself.

\section{Making Sense of the Profusion}

Over the course of some 150 years, animals that many have considered to be the same species have been placed in at least 


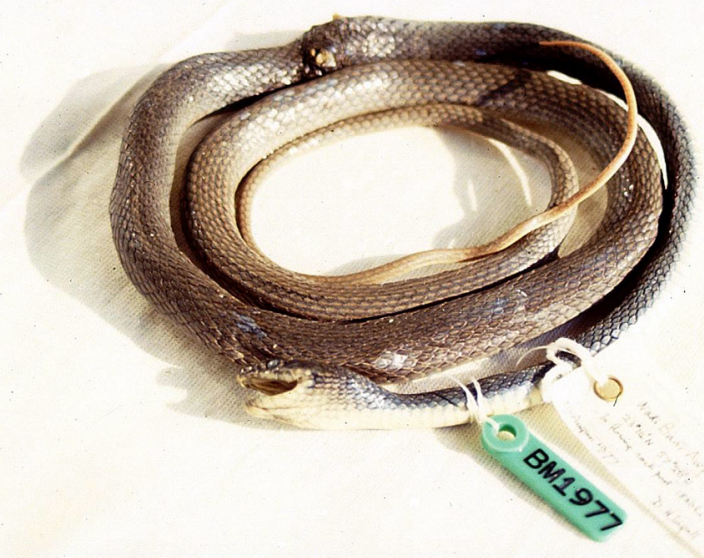

Fig. 9. The melanistic form found throughout much of Arabia - a specimen from Oman photographed at the Natural History Museum in London. The correct name for these animals remains unclear. Photograph by Gad Perry.

six genera: Zamenis, Gonyosoma, Coluber, Haemorrhois, and most recently, Platyceps and Eremiophis. Species and subspecies have been proposed and sunk, and names have been misspelled in a variety of ways. Type specimens have been lost or otherwise become unavailable. To make things even more complicated, countries have come and gone, changed names, and fought over borders. Kashmir, from which both Z. ladacensis and C. rhodorachis kashmirensis were described, remains a bone of contention between India and Pakistan. No wonder the task of untangling which name deserves to exist, which is just a renamed existing form, and which valid taxon is found where is so difficult.

Two primary characteristics appear to reliably separate the named forms: Color pattern, best compared at the neck region (Fig. 6) and number of ventral scales. To try and disentangle the confusing literature references, I examined 168 live and preserved animals in the collections of the Natural History Museum in London (BMNH), Hebrew University of Jerusalem (HUJ), Institut Royal des Sciences Naturelles de Belgique (IRSNB), Natural History Museum in Berlin (NHMB), Tel Aviv University (TAU), and Zoologisches Museum Berlin ( $\mathrm{ZMB})$. The countries included in this sample are Aden, Afghanistan, Egypt, "Gulf States," India, Iran, Israel, Jordan, Oman, Saudi Arabia, "Somaliland," Turkmenistan, and Yemen. I also added data on 11 animals for which authors provided, at a minimum, individual locality and ventral count data, as well as a clear indication that they were not included in the collections where animals were examined (Anderson 1871, 1872, 1895, 1901; Schmidt 1939; Shockley 1949; Minton 1966). This enhanced the sample size for several countries and provided information for Iraq and Pakistan, not previously represented. Almost all snakes included in the dataset clearly belonged in one of five morphological categories: "Southern Israel" $(\mathrm{N}=61$; Figs. $1-2)$, "northern Israel” ( $\mathrm{N}=44$; Fig. 5), red-striped ( $\mathrm{N}=9$;

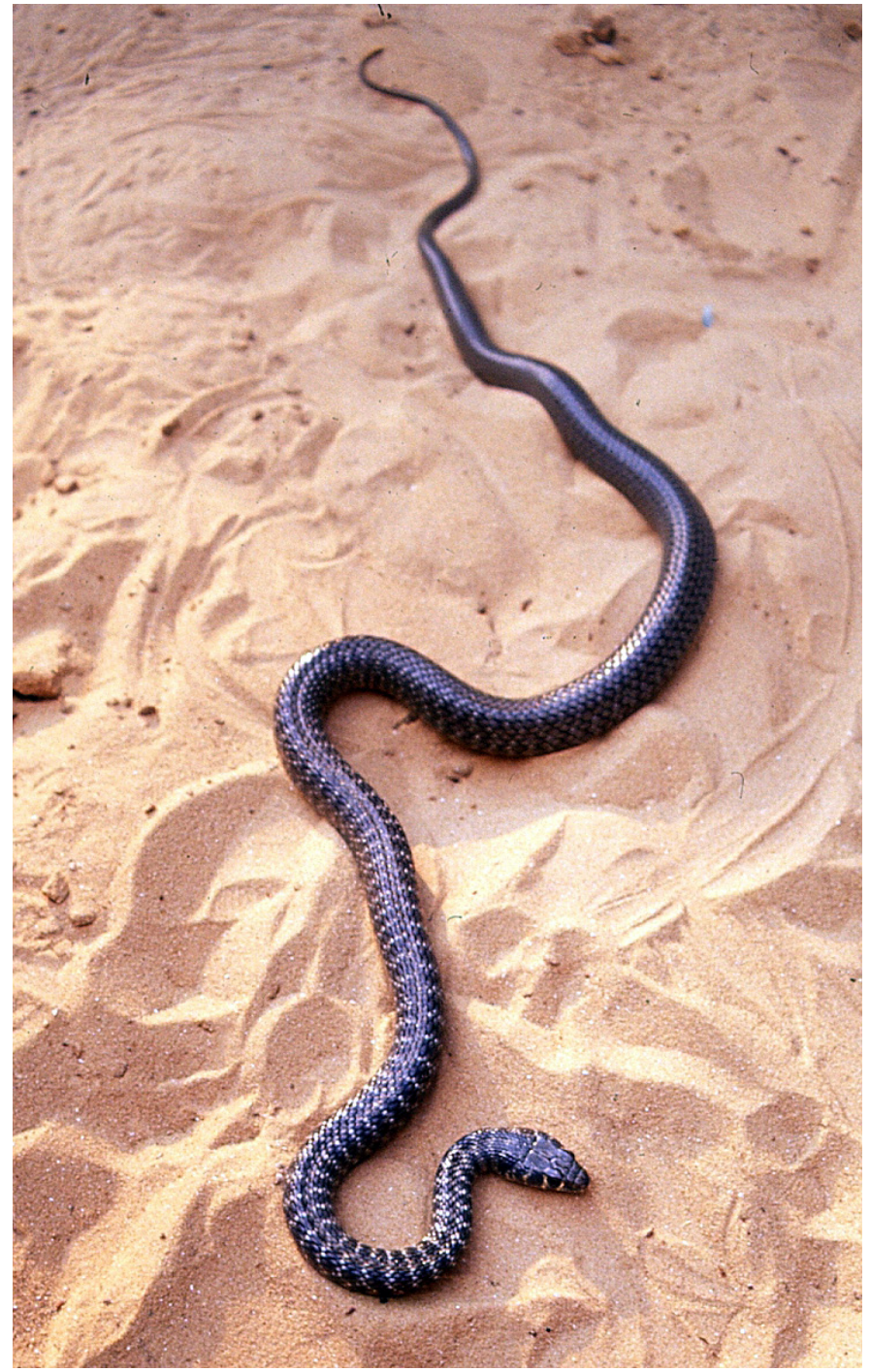

Fig. 10. A melanistic form found on the Egyptian island of Tiran, between the Red Sea and the Gulf of Aqaba. This animal was photographed live at the I. Meier Segals Garden for Zoological Research at Tel Aviv University. The correct name for these animals remains unclear. Photograph by Gad Perry.

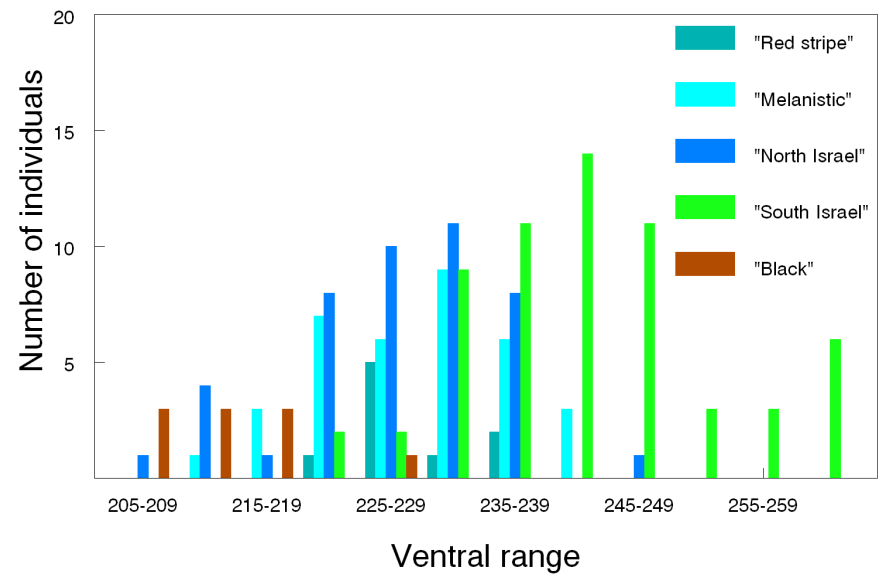

Fig. 11. Ventral counts of "Coluber rhodorachis" from the entire distribution range. Colors separate color phenotypes, and the three forms in shades of blue do not differ significantly from each other but do differ from the remaining two forms. 
Figs. 7-8), melanistic ( $\mathrm{N}=35$, Figs. 9-10), or black $(\mathrm{N}=10)$. A one-way ANOVA showed highly significant differences in ventral scale counts overall $\left(\mathrm{F}_{5,154}=38.1, \mathrm{P}<0.001\right.$; Fig. 11). A Student-Newman-Keuls post-hoc test identified three distinct groupings: black snakes from "Somaliland," with an average ventral count of 214.4; the "southern Israel" snakes, with an average ventral count of 242.5; and the other three forms, with average ventral counts of 227.5-229.1. Ventral counts often differ between sexes and along geographic gradients, but the data were not sufficiently detailed to allow those factors to be assessed.

\section{Conclusions}

Science is a process of making observations, organizing them into hypotheses, repeatedly testing them in light of increasingly more extensive data and more sophisticated analysis methods, and supporting or rejecting pre-conceived notions. To a scientist, support for one's hypothesis is very satisfying, but the opposite is sometimes more instructive. In the current exam- ple, more information was available than in many such studies, but it is contradictory, confusing, and primarily limited to morphological characters. Most of the taxonomic hypotheses I examined, including my own (Perry 1985), turned out to have been wrong. Genetic work may ultimately be needed to sort out the relationships between these animals, but some conclusions appear possible based on existing information.

Coluber rhodorachis rhodorachis is the original designation for animals also identified as Gonyosoma dorsale, a junior synonym. As originally described by Jan (1865) and Anderson (1872), this is a slender desert snake with a prominent red vertebral stripe and no cross-bands. This taxon has a limited distribution in Iran and some of the former Russian republics in Asia (e.g., Terent'ev and Chernov 1949, p. 222; Latifi 1991). As viewed here, the proper name for these animals is Platyceps rhodorachis (Fig. 7). Contrary to some reports, the stripe does not fade in preservative - specimens I examined in the collections of the British Museum retained a clear stripe many decades after collection (Fig. 8).

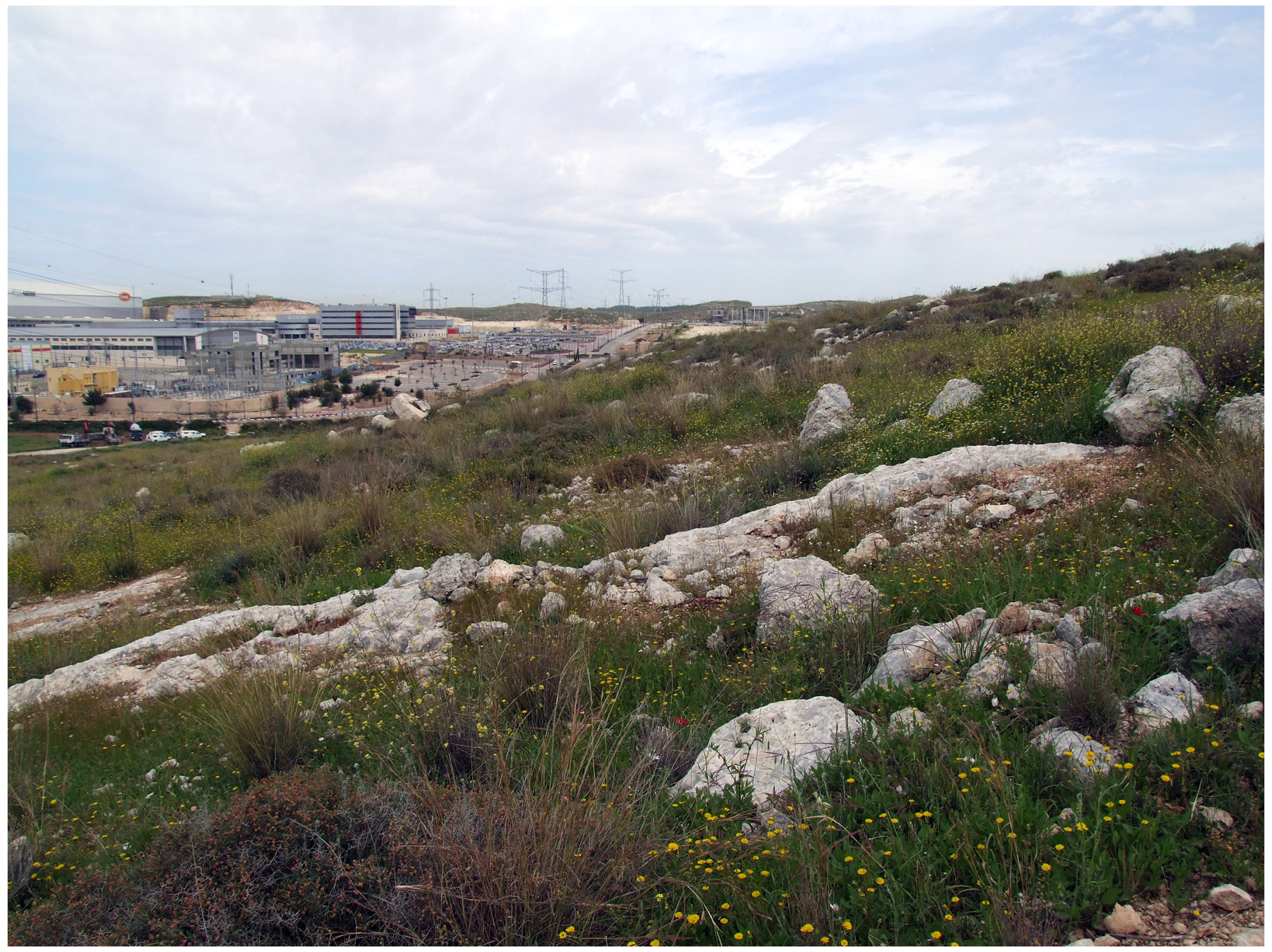

Fig. 12. Collection location of the Platyceps ladacensis shown in Fig. 5, in eastern central Israel. Photograph by Boaz Shacham. 


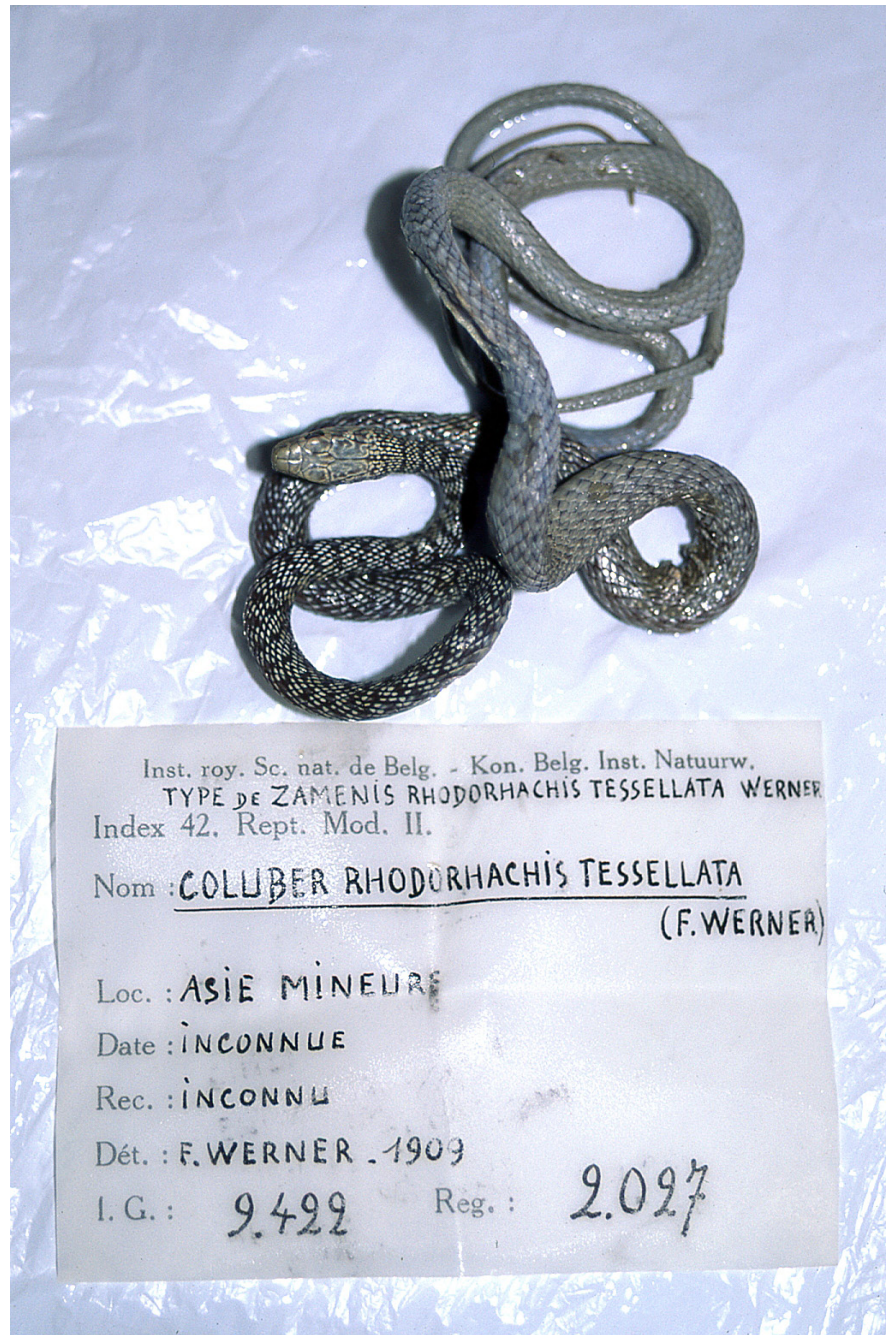

Fig. 13. The type specimen of Platyceps tessellata, located at the Institut Royal des Sciences Naturelles de Belgique. Photograph by Gad Perry.

Zamenis ladacensis, now generally referred to as C. r. ladacensis or $P$. $r$. ladacensis, is a valid taxon and the appropriate designation for the form referred to above as "northern Israel" (Fig. 5). The history of this taxon is especially instructive of the dangers of excessive deference to scientific authorities. Having described it, Anderson almost immediately - and erroneously - followed the lead of Boulenger, perhaps the leading herpetological authority of the time, and treated it as a synonym. The ventral count of the (now lost) type specimen, 237 (Anderson 1871) is well within the range of counts identified in the current study (209-245). This is the phenotype seen in India, and the one identified and illustrated as Platyceps rhodorachis rhodorachis from Pakistan (Khan 2006, p 206). It is also the form that Schätti and McCarthy (2004) assigned to "Platyceps sp. incertae sedis" (literally, "of uncertain placement"). This taxon is very broadly distributed, ranging from Israel in the west to India in the northeast to Yemen in the south, and is typically found in mesic environments (Fig. 12). Given the lack of overlap or intergradation in Israel, which also has the following form, it should be elevated to species level and named Platyceps ladacensis (Anderson 1871).

Zamenis rhodorhachis var. tessellata, described by Werner (1909) from an almost certainly incorrect locality, has been ignored by most subsequent authors. The type specimen (Fig. 13) has both the appearance and a ventral scale count (244) typical of what was earlier called the "southern Israel" morph (223-264) in the current study. The location of the type specimen was given as "Asie Mineure," now Turkey. Given all that is know about the distribution of these taxa, this appears likely to be an error, as suggested by Werner (1909) himself and Bodenheimer (1944). Indeed, Başoğlu and Baran (1980) did not include this species in their summary of the herpetofauna of Turkey, and den Bosch (1998) did not list it as a resident of Lebanon. These desert-dwelling animals (Fig. 14) have been variously referred by different authors to almost all of the names and misspelled names listed above. Based on range, appearance, and scale counts, these also are the animals that Schätti and McCarthy (2004) named Platyceps saharicus, a junior synonym. Following the logic above, the proper name for these animals (Fig. 1) is Platyceps tessellata (Werner 1909). They range from Israel and the Palestinian Authority in the north to Saudi Arabia in the south and from Algeria in the west to Oman in the east (Schätti and McCarthy 2004, Geniez and Gauthier 2008). Animals from Eritrea and Ethiopia identified by Largen and Spawls (2010) as $P$. rhodorachis most likely also belong to this taxon.

Boettger (1893) named Z. ladacensis, var. subnigra (sometimes spelled subniger) from Ogaden, Somalia, and a variety of authors (e.g., Anderson 1901, Smith 1943, Schätti and Ineich 2004) have since suggested that such animals might more properly be considered a separate species. The current analysis supports this conclusion, and this form should be named Platyceps subnigra (Boettger 1893). This species has a limited and poorly-studied range, primarily in what is now Somalia and Somaliland and in parts of what is now Ethiopia and Eritrea.

The status of the many melanistic "Coluber rhodorachis" found throughout the range (Figs. 9-10), mentioned by various authors and illustrated by Leviton et al. (1992, plate 15 $\mathrm{D})$, is much less clear. These are distinct from the subnigra form in terms of appearance, distribution, and scale counts, but except by coloration, they are not easily distinguished from ladacensis, with which they broadly share both range and scale counts. This is possibly a melanistic form of ladacensis, although melanistic animals do not occur everywhere where the latter form is found. Alternatively, some or all of these "gray" snakes belong to $P$. florulentus, as suggested by Largen and Spawls (2010), or represent yet another hitherto undescribed species. Animals from the island of Tiran (Egypt), uniformly dark (Fig. 10), are similarly hard to place.

I was unable to examine any specimens of kashmirensis, and the only complete picture available (Khan 2006, p. 


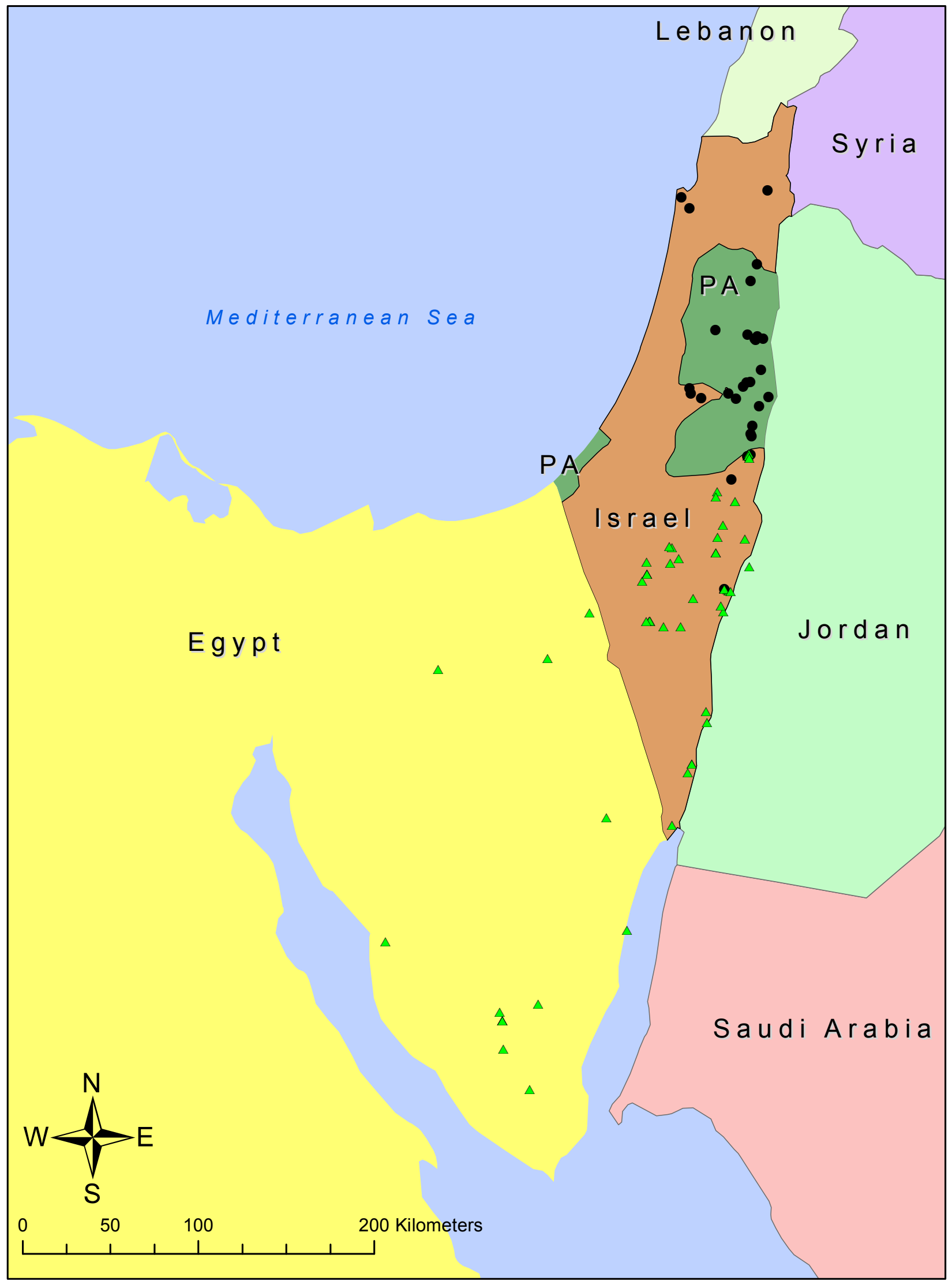

Fig. 14. Distribution of Platyceps tessellata (green triangles) and P. ladacensis (black circles) in Israel, the Palestinian Authority (PA), and part of Egypt. Only animals for which exact locality could be established were included. Graphic by Boaz Shacham. 
$207)$ is of a preserved animal in less than ideal condition. In describing the form, Khan and Khan (2000) stated: "Head and anterior half of body black with no indication of spotting," although the picture they provided of the head region (their fig. 3 C) does show some spotting. The written description in Khan (2006, p. 207) matches those in Khan and Khan (2000) and Khan (2002), but the picture provided on the same page does not; it instead shows a spotted animal. Khan (2002) did not provide a picture of this taxon. As noted by Schätti and Schmitz (2006), "Khan (2002) is full of contradictory information ... and a plethora of minor errors and carelessness about details." Meaningful assessment of the validity of that form must therefore await the availability of specimens.

The phylogenetic relationships of all these forms to one another and to $P$. afarensis, recently described by Schätti and Ineich (2004), are unclear at this time. Given the great morphological similarities among them, genetic material will likely be needed to disentangle the evolutionary history of this complex radiation.

As for me, I have learned my lesson. What seemed like a small project several decades ago remains not fully resolved today. In the future, I will let taxonomists do the legwork. After all, most of the time, we ecologists simply need an accurate label to hang on the animal we are studying, and do not really care that much what the label is.

\section{Acknowledgements}

I thank Y.L. Werner for his many years of interest in this project and his active encouragement to complete it. Curators at several institutions, including E.N. Arnold, H. Garner, E. Kramer, K. Lang, C. McCarthy, the late H. Mendelssohn, M.-O. Rödel, and J. Vindum provided invaluable help. B. Schätti, the late J.H. Hoofien, and M.S. Khan kindly discussed various parts of this work with me over the years. B. Schacham helped produce some of the graphics used and discussed the habitat for the "northern Israel" form. This is manuscript T-9-1217 of the College of Agricultural Sciences and Natural Resource Management, Texas Tech University.

\section{Literature Cited and Additional Pertinent References}

Anderson, J. 1871. A list of the reptilian accession to the Indian Museum, Calcutta, from 1865 to 1870 , with a description of some new species. Journal of the Asiatic Society of Bengal 40:12-39.

Anderson, J. 1872. On some Persian, Himalayan, and other reptiles. Proceedings of the Zoological Society of London 1872:371-404.

Anderson, J. 1895. On a collection of reptiles and batrachians made by Colonel Yerbury at Aden and its neighbourhood. Proceedings of the Zoological Society of London 1895:635-663.

Anderson, J. 1898. Zoology of Egypt. Volume I: Reptilia and Batrachia. Bernard Quaritch, London.

Anderson, J. 1901. A list of reptiles and batrachians obtained by Mr. A. Blayney Percival in Southern Arabia. Proceedings of the Zoological Society of London 2:137-152.
Arbel, A. (ed.) 1984. Plants and Animals of the Land of Israel. Volume 5: Reptiles and Amphibians. Ministry of Defence and Society for Protection of Nature in Israel, Tel Aviv (in Hebrew).

Barash, A. and J.H. Hoofien. 1966. Reptiles of Israel. Hakibutz Hameuchad, Israel (in Hebrew).

Ba o lu, M. and I. Baran. 1980. The reptiles of Turkey part II: The snakes. Ege Üniversitei Fen Fakültesi Kitaplar Serisi 81:173-190 (in Turkish).

Bodenheimer, F.S. 1935. Animal Life in Palestine. Sefer, Jerusalem.

Bodenheimer, F.S. 1944. Introduction into the knowledge of the Amphibia and Reptilia of Turkey. Istanbul Üniversitei Fen Fakültesi Mecmuasi B 9:1-93.

Boettger, O. 1893. Übersicht der von Prof. C. Keller anlässlich der Ruspoli’schen Expedition nach den Somaliländern gesammelten Reptilen und Batrachier. Zoologischen Anzeiger 16:113-119, 129-132.

Boulenger, G.A. 1893. Catalogue of the Snakes in the British Museum. Volume I. Trustees of The British Museum (Natural History), London (reprinted 1961 by Wheldon and Wesley Ltd. and Verlag Cramer).

Geniez, P. and Y. Gauthier. 2008. On the distribution of Platyceps saharicus (Reptilia: Colubridae) in the Sahara. Salamandra 44:179-180.

Günther, A. 1858. Catalogue of the Colubrine Snakes in the Collection of the British Museum. Trustees of The British Museum (Natural History), London.

in den Bosch, H.A.J. 1988. Prodromus einer Liste der Amphibien und Reptilien Libanons. Faunistische Abhandlungen des Stattlichen Museum für Tierkunde, Dresden 21(supplement):9-17.

Inger, R.F. and P.J. Clark. 1943. Partition of the Genus Coluber. Copeia 1943:141145.

Jan, G. 1865. In: F. De Filippi, Note di un Viaggio in Persia, nels 1862. Volume Unico. G. Daelli \& C. Editori, Milano.

Jongbloed, M. and J.N.B. Brown. 2000. Wild about Reptiles: Field Guide to the Reptiles and Amphibians of the UAE. Barker Trident Communications, London.

Khalaf, K.T. 1959. Reptiles of Iraq, with Some Notes on the Amphibians. Ar-Rabitta Press, Baghdad.

Khan, M.S. 1997. Taxonomic notes on Pakistani snakes of the Coluber carelinirhodorachis-ventromaculatus species complex: A new approach to the problem. Asiatic Herpetological Research 7:51-60.

Khan, M.S. 2002. A Guide to the Snakes of Pakistan. Chimaira, Frankfurt am Main, Germany.

Khan, M.S. 2006. Amphibians and Reptiles of Pakistan. Krieger Publishing Co., Malabar, Florida.

Khan, M.S. and A.Q. Khan. 2000. Three new subspecies of snakes of the genus Coluber from Pakistan. Pakistan Journal of Zoology 32:49-52.

Kudrjavtsev, S.V. and S.V. Mamet. 1989. Terrestrial snakes of the Soviet Union. Snake 21:29-35

Largen, M. and S. Spawls. 2010. The Amphibians and Reptiles of Ethiopia and Eritrea. Chimaira, Frankfurt, Germany.

Latifi, M. 1991. The Snakes of Iran. Society for the Study of Amphibians and Reptiles, Oxford, Ohio.

Lawson, R., J.B. Slowinski, B.I. Crother, and F.T. Burbrink. 2005. Phylogeny of the Colubroidea (Serpentes): New evidence from mitochondrial and nuclear genes. Molecular Phylogenetics and Evolution 37:581-601.

Leviton, A.E. and S.C. Anderson. 1961. Further remarks on the amphibians and reptiles of Afghansitan. Wasmann Journal of Biology 19:269-276.

Leviton, A.E. and S.C. Anderson. 1963. Third contribution to the herpetology of Afghanistan. Proceedings of the California Academy of Sciences, fourth series 31:329-339.

Leviton, A.E., S.C. Anderson, K. Adler, and S.A. Minton. 1992. Handbook to Middle East Amphibians and Reptiles. Society for the Study of Amphibians and Reptiles, Oxford, Ohio.

Minton, S.A., Jr. 1966. A contribution to the herpetology of West Pakistan. Bulletin of the American Museum of Natural History 134:27-184.

Nagy, Z.T., R. Lawson, U. Joger, and M. Wink. 2004. Molecular systematics of racers, whipsnakes and relatives (Reptilia: Colubridae) using mitochondrial and nuclear markers. Journal of Zoological Systematics and Evolutionary Research 42:223-233.

Parker, H.W. 1949. The snakes of Somaliland and the Sokotra Islands. Zoologische Verhandelingen, Rijksmuseum van Natuurlijke Historie, Leiden 6:1-115. 
Perry, G. 1985. A new subspecies of Coluber rhodorachis (Ophidia: Colubridae) from Israel. Israel Journal of Zoology 33:123.

Schätti, B. 1987. The phylogenetic significance of morphological characters in the Holarctic racers of the genus Coluber Linneaus, 1758 (Reptilia, Serpentes). Amphibia-Reptilia 8:401-418.

Schätti, B. and I. Ineich. 2004. A new racer of the genus Platyceps from Djibouti (Reptilia: Squamata: Colubrinae). Revue Suisse de Zoologie 111:685-690.

Schätti, B. and C. McCarthy. 2004. Saharo-Arabian racers of the Platyceps rhodorachis complex - description of a new species (Reptilia: Squamata: Colubrinae). Revue Suisse de Zoologie 111:691-705.

Schätti, B. and A. Schmitz. 2006. Re-assessing Platyceps ventromaculatus (Gray, 1834) (Reptilia: Squamata: Colubrinae). Revue Suisse de Zoologie 113:747768.

Schleich, H.H., W. Kästle, and K. Kabisch. 1996. Amphibians and Reptiles of North Africa. Koeltz Scientific Books, Koenigstein, Germany.

Sclater, W.L. 1891. Notes on a collection of snakes in the Indian Museum with description of several new species. Journal of the Asiatic Society of Bengal 60:230-250.

Schmidt, K.P. 1939. Reptiles and amphibians from southwestern Asia. Field Museum of Natural History, Zoological Series 24:49-92.

Shockley, C.H. 1949. Herpetological notes from Ras Jiunri, Baluchistan. Herpetologica 5:121-123.
Smith, M.A. 1943. The Fauna of British India, Reptilia and Amphibia, Volume 3: Serpents. Taylor and Francis, London.

Sochurek, E. 1979. Die Schlangen Nordafrikas. Mitteilungen der Zoologischen Gesellschaft Braunau 3:219-226.

Terent'ev, P.V. and S.A. Chernov. 1949. Key to Amphibians and Reptiles. Sovetskaya Navka, Moscow (translated and reprinted 1965, Israel Program for Scientific Translations, Jerusalem).

Utiger, U., N. Helfenberger, B. Schätti, C. Schmidt, M. Ruf, and V. Ziswiler. 2002. Molecular systematics and phylogeny of Old and New World ratsnakes, Elaphe Auct., and related genera (Reptilia, Squamata, Colubridae). Russian Journal of Herpetology 9:105-124.

Utiger, U., B Schätti, and N. Helfenberger. 2005. The Oriental colubrine genus Coelognathus Fitzinger, 1843 and classification of Old and New World racers and ratsnakes (Reptilia, Squamata, Colubridae, Colubrinae). Russian Journal of Herpetology 12:39-60.

Vogel, Z. 1954. Aus dem Leben der Reptilien. Artia, Prague.

Welch, K.R.G. 1982. Herpetology of Africa: A Checklist and Bibliography of the Orders Amphisbaenia, Sauria and Serpentes. Krieger Publishing Co., Malabar, Florida.

Werner, F. 1909. Neue oder seltenere Reptilien des Musée Royal d'Histoire Naturelle de Belgique in Brüssel. Zoologische Jahrbücher (Systematik) 28:263288. 